what they can to guard themselves against it. They begin to purify their houses by lighting fires in every room, and in certain towns they abstain from pork. Mr. Rocher gives details as to the symptoms and conrse of the disease. With regard to the track of the epidemic Mr. Rocher observed a peculiar fact both in the north and south of the province. Instead of visiting every village in its direct line of progress it would pass some completely by, visiting places near them and on both sides, to return to those forgotten spots several months afterwards, when the epidemic would appear to have passed far away. Another fact not less curious is that after having appeared in almost every one of the villages scattered about the plains, it frequently ascends the mountains, where, among the aborigines who inhabit the high lands, it claims many victims. We may add that $\mathrm{Mr}$. Rocher's notes are accompanied by a map, compiled from private and official memoranda, which shows the course followed by the plague in 1871,72 , and 73 ; it was not possible, however, to include in it the towns in the west of the province, which was at that time the theatre of the war between the Imperialists and the Mahometan rebels, as the information obtainable was quite untrustworthy, but it is certain that the epidemic was constantly present among the Imperialist troops.

THE additions to the Zoological Society's Gardens during the past week include a Green Monkey (Cercopithecus callitrichus) from West Africa, presented by Miss G. E. Marryat ; a Bonnet Monkey (Macacus radiatus) from India, presented by Mr. F. Hinde; two Horsfield's Tortoises (Testzdo horsfielda) from Turkestan, presented by Dr. Alex. Strauch, C.M.Z.S.; a Wanderoo Monkey (Macacus silknus) from Malabar, two Egyptian Jerboas (Dipus agytius) from Egypt, a Sun Bittern (Eurypyga helius) from South America, deposited; a Woodcock (Scolopax rusticola), European, purchased.

\section{CHARLES ADOLPHE WURTZ}

$\mathrm{N}$ connection with the Faraday Lecture which follows, it may interest our readers to have a few particulars as to the life and work of the lecturer, Prof. Wurtz.

Charles Adolphe Wurtz was born at Strassburg on November 16,1817 . He commenced his chemical career as assistant to Dumas, and first acquired an independent position as professor at the Agricultural Institute at Versailles. For the last thirty years he has been Professor of Chemistry at the École de Médecine, Paris; in addition to which he now holds the post of Professor of Chemistry at the Sorbonne.

Prof. Wurtz is a member of the Institute (Académie des Sciences), and a foreign Fellow of the Royal Society.

Some idea of the energy which he has displayed as an investigator is conveyed by the fact that a list of no less than seventy-three titles of papers is appended to his name in the Royal Society Catalogue, which only includes papers published previous to 1864 . Much of his work is of the first importance in connection with chemical theory, and he undoubtedly takes rank as one of the chief pioneers of modern organic chemistry.

His first investigation, published in 1842 , was on the constitution of the hypophosphites; this was followed by researches on phosphorous acid, sulpho-phosphoric acid, Sic., which greatly added to our knowledge of the phosphorus compounds. It was in the course of his experiments on the hypophosphites that Wurtz discorered hydride of copper, $\mathrm{Cu}_{2} \mathrm{H}_{2}$, one of the most remarkable hydrides with which we are acquainted, and especially interesting as, with the exception of potassium, sodium, and perhaps palladium, none of the metals appear to be capable of combining with hydrogen. Hydride of copper is formed as a yellowish precipitate on adding a concentrated solution of copper sulphate to a solution of hypophosphorous acid, and warming the mixture to about $70^{\circ} \mathrm{C}$.; in the dry state it slowly decomposes into its constituents at about $55^{\circ} \mathrm{C}$. ; concentrated hydrochloric acid at once dissolves it with evolution of hydrogen, although copper is not in the least affected by this acid, and what is most remarkable, both the hydrogen of the acid and of the hydride of copper are given off as shown by the equation-

$$
\mathrm{Cu}_{2} \mathrm{H}_{2}+2 \mathrm{HCl}=\mathrm{Cu}_{2} \mathrm{Cl}_{2}+2 \mathrm{H}_{2} \text {. }
$$

The study of certain cyanogen compounds-the cyanic and cyanuric ethers-next engaged his attention, and his researches on these bodies culminated in the remarkable discovery, in 1849, of the so-called compound ammonias formed by the displacement of one of the atoms of hydrogen in ammonia, $\mathrm{NH}_{3}$, by organic radicles, such as methyl, $\mathrm{CH}_{3}$, ethyl, $\mathrm{C}_{2} \mathrm{H}_{5}$, \&c.

A third investigation to which we may here refer is that on the alcohol radicles published in 1855. Frankland had shown that the hydrocarbon radicles which it was assumed were contained in the alcohols could actually be isolated; that, from ordinary or etbyl acohol, for example, which may be regarded as a compound of the radicle ethyl, $\mathrm{C}_{2} \mathrm{H}_{5}$, with the radicle $\mathrm{OH}$, we may obtain ethyl by acting with zinc on the iodide which it yields on treatment with hydriodic acid, thus withdrawing the iodine from it, just as the iodine is withdrawn from the hydrogen in hydriodic acid by the action of metals ; and Kolbe had obtained similar results with acids, such as acetic acid, by submitting solutions of their salts to the action of a powerful electric current. These chemists, however, supposed that the radicles thus withdrawn from combination with other radicles remained in the free state, but Laurent and Gerhardt, and Hofmann argued on theoretical grounds that the bodies thus produced were not the radicles themselves but compounds of the radicles with themselves - that ethyl, for example, was not $\mathrm{C}_{2} \mathrm{H}_{5}$, but $\mathrm{C}_{4} \mathrm{H}_{10}$ or $\mathrm{C}_{2} \mathrm{H}_{5}+\mathrm{C}_{2} \mathrm{H}_{5}$. Conclusive evidence of the correctness of this latter view was afforded by Wurtz's discovery that if a mixture of the jodides of two different radicles were treated with metallic sodium, a hydrocarbon formed by the union of the two different radicles was obtained. This discovery has afforded one of the chief arguments in favour of the view now almost universally entertained by chemists, that free hydrogen is a compound of hydrogen with hydrogen.

The mere recapitulation of the titles of his remaining investigations would alone occupy a large amount of space. We can only refer to those on the glycols and on ethylene oxide; on the action of nascent bydrogen on aldehyde; on the action of chlorine on aldehyde, both in the anhydrous state and in presence of water; on the action of hydrochloric acid on aldehyde; on the synthesis of neurine; and on abnormal vapour densities, as being, among others, of especial interest.

\section{ON THE CONSTITUTION OF MATTER IN THE GASEOUS STATE}

\section{LADIES AND GENTLEMEN, -}

I ESTEEM it a great honour to address you within these walls, about which there still hovers the ever fresh memory of him whose name we celebrate to-day, while we deplore his loss. I am fully sensible both of the great value of this honour and of the danger that attends it, and I have need to shelter myself under the authority of the great name of FARADAY. I have, therefore, chosen a subject connected with his earliest discoveries. The constitution of matter is a question of the highest importance with regard both to physics and to chemistry.

The word " $\mathrm{g}$ as" was introduced into science by Van Helmont, who, at the beginning of the seventeenth century, first pointed out, with some degree of precision, the differences existing be-

I The Faraday lecture, delivered before the Fellows of the Chemical Society, in the Theatre of the Royal Institution, on Tuesday, November 12 1879 , by Ad. W urt z, Membre de l'Institut; Doyen Honoraire de la Faculty de Médecine de Paris. 